Dikirim: 13 Juni 2016 Diterbitkan: 1 Desember 2016

\section{Analisis beban ekonomi kejadian luar biasa campak di Daerah Istimewa Yogyakarta tahun 2015}

\section{Economic burden analysis of measles outbreak in the Special Region of Yogyakarta 2015}

Akhmad Mukhibin $^{1}$, Riris Andono Ahmad ${ }^{1}$, Hari Kusnanto ${ }^{1}$

\section{Abstract}

Purpose: This study aimed to analyze the economic burden due to outbreaks of measles in the household sector in Yogyakarta. Methods: This research was a descriptive study with survey design, with data collected of direct and indirect costs for patients exposed to measles, by conducting interviews of 177 respondents using a questionnaire. Secondary data was compared in the form of outbreaks of measles in 2014 and 2015, to research in February-March, 2016. Results: The number of outbreaks of measles patients who visited health facilities reached 163 patients (92.09\%). Total medical costs were IDR 17.982.000, non-medical costs IDR 7.804.900, so the total direct cost of IDR was 25.786.900 (average IDR 145. 700). Total indirect costs were IDR 11.720 .000 (average IDR 156. 300). The economic burden of measles outbreak was IDR 37.506.900 (average IDR 211. 900). Generally, the cost that is paid out of pocket amounted to $6.32 \%$ of household income, not yet considered catastrophic. Regression analysis showed the duration of illness averaged more than 10 days $(p=0.002$ with some status of hospitalization $(p=0.000)$. Conclusions: The economic burden of outbreaks of measles in the province in 2015 was IDR 37.506.900, including direct and indirect costs. Medical costs are the dominant component of direct costs. The factors that were related to the economic burden are the duration of illness of more than 10 days and inpatient status. There needs to be an advocacy to the community about the use of health care and prevention of measles by way of measles immunization.

Keywords: cost; economic burden; measles outbreak

${ }^{1}$ Departemen Biostatistik, Epidemiologi, dan Kesehatan Populasi, Fakultas Kedokteran, Universitas Gadjah Mada (Email: ibin_akhmad@yahoo.com) 


\section{PENDAHULUAN}

Penyakit menular campak disebabkan oleh virus. Campak masih menjadi penyebab utama kematian anak-anak secara global, meskipun vaksin yang aman dan hemat biaya sudah tersedia (1). Indonesia membuat kemajuan substansial dalam upaya pengendalian campak, dimana dilaporkan terjadi penurunan kasus campak sebesar 76,6\%. Kementerian Kesehatan melaporkan 55.348 kasus campak tahun 2006 dan hanya 12.943 kasus yang dilaporkan pada tahun 2014 . Selain itu, jumlah kematian yang disebabkan oleh campak mengalami penurunan sebesar $36,36 \%$ dari total 44 kematian pada 2006 menjadi 28 kematian pada tahun 2014 (2).

Terdapat pencapaian signifikan pengendalian campak di Indonesia, namun campak masih menjadi masalah yang serius dan berpotensi menimbulkan kejadian luar biasa (KLB). Berdasarkan data Kementerian Kesehatan, sejak tahun 2006 tren KLB campak cenderung mengalami peningkatan. Secara keseluruhan jumlah KLB yang dilaporkan meningkat hingga 50,28\%, dari 86 KLB tahun 2006, menjadi 173 KLB tahun 2014 (2).

Kasus campak tahun 2014 tersebar di seluruh provinsi di wilayah Indonesia, salah satunya adalah di Provinsi DIY dengan jumlah kasus 1.222 kasus. DIY merupakan provinsi dengan jumlah kasus campak terbanyak ketiga setelah DKI Jakarta dan Aceh. Frekuensi KLB campak di Provinsi DIY masih cukup tinggi. Frekuensi KLB berdampak pada sektor ekonomi baik pemerintah, swasta dan rumah tangga. Berdasarkan penelitian sebelumnya tentang beban ekonomi akibat KLB campak yang dilakukan di Jepang menunjukkan bahwa besar biaya yang dikeluarkan untuk pengobatan campak pada saat KLB diperkirakan mencapai US\$ 404 juta. Jumlah tersebut jauh lebih besar daripada biaya vaksinasi yang hanya US\$ 165 juta (3). Studi lain di Italy pada pasien rawat inap akibat KLB campak menunjukan bahwa biaya langsung yang dikeluarkan untuk campak men- capai €17.6-22.0 juta yang setara dengan vaksinasi bagi 1,5-1,9 juta anak dengan satu dosis vaksin Measles, Mumps dan Rubela (MMR) (4).

Penelitian di Netherland tentang beban ekonomi KLB campak pada tahun 2013-2014 dengan populasi penelitian pada komunitas masyarakat protestan ortodox Netherland dengan cakupan imunisasi yang rendah, menunjukan bahwa KLB campak yang terjadi selama 2013-2014 diestimasi menimbulkan beban ekonomi sebesar 4,7 juta USD atau setara dengan Rp. 61.100.000.000. Sedangkan estimasi biaya per kasus sebesar 1.739 USD atau setara dengan Rp. 22.607.000 per kasus dengan jumlah kasus yang dilaporkan sebesar 2700 kasus (5).

Penelitian ini bertujuan menganalisis beban ekonomi akibat KLB campak pada sektor rumah tangga. Ketersediaan informasi diharapkan memberikan kontribusi penyusunan kebijakan pengendalian campak di provinsi DIY. Hal ini juga dapat membantu petugas imunisasi pada saat advokasi untuk meningkatkan sumber daya yang secara khusus dialokasikan untuk pengendalian campak.

\section{METODE}

Penelitian deskriptif ini menggunakan desain survei untuk mengestimasi biaya yang dikeluarkan akibat KLB campak pada sektor rumah tangga di provinsi DIY serta menganalisis karakteristik rumah tangga yang berhubungan dengan beban ekonomi KLB campak. Pengumpulan data primer berupa biaya langsung dan tidak langsung yang terjadi selama mencari dan memperoleh pengobatan campak sampai pasien sembuh dari campak diambil melalui wawancara menggunakan kuesioner kepada penderita atau anggota keluarga. Data sekunder diperoleh dari dinas kesehatan Provinsi DIY yaitu data kejadian luar biasa campak selama tahun 2014 dan 2015. Penelitian dilaksanakan di Daerah Istimewa Yogyakarta (Kabupaten Bantul, Sleman, Kulon Progo, Gunung Kidul dan Kota Yogyakarta), pada bulan Februari-Maret 2016.

Populasi adalah rumah tangga yang memiliki anggota keluarga pernah terkena penyakit campak dan terdaftar sebagai pasien KLB campak periode Mei 2014 sampai dengan 2015 yang memenuhi kriteria inklusi. Kriteria inklusi adalah seseorang yang didiagnosis campak periode bulan Mei 2014 sampai dengan 2015 dan terdaftar sebagai pasien KLB campak atau mempunyai hubungan epidemiologis dengan kasus KLB campak di wilayah DIY. Kriteria ekslusi adalah pasien KLB campak/orang tua/wali/pengasuh pada saat penelitian tidak berada di wilayah DIY/ cacat yang menyebabkan hilang ingatan/meninggal dunia.

Analisis menggunakan software STATA versi 12.1. Analisis fokus pada estimasi biaya ekonomi akibat KLB campak di sektor rumah tangga, yaitu biaya langsung dan biaya tidak langsung yang digunakan untuk memberikan perkiraan keseluruhan biaya KLB campak di sektor rumah tangga. Ketika keseluruhan biaya telah dihitung, selanjutnya dibuat perhitungan nilai mean, median dan Interquartil range (IQR). Analisis lebih lanjut dilakukan untuk mengetahui hubungan karak- 
teristik rumah tangga dengan beban ekonomi akibat KLB campak. Penelitian ini telah melalui proses uji kelaiakan etika penelitian di Fakultas Kedokteran Universitas Gadjah Mada Yogyakarta.

\section{HASIL}

Karakteristik pasien KLB campak dalam penelitian ini berdasarkan demografi dan sosio ekonomi menunjukkan bahwa jumlah pasien perempuan lebih banyak daripada laki-laki. Pasien KLB campak terbanyak adalah pada golongan usia 5-9 tahun. Sebagian besar pasien KLB campak tinggal/berdomisili di wilayah pedesaan. Mayoritas responden mengaku telah diimunisasi campak. Distribusi frekuensi karakterisrik pasien KLB campak.

Tabel 1. Distribusi frekuensi karakteristik pasien KLB campak di Provinsi DIY tahun 2015

\begin{tabular}{|c|c|}
\hline Variabel & $\begin{array}{c}\text { Persentase (\%) } \\
(n=177)\end{array}$ \\
\hline \multicolumn{2}{|l|}{ Jenis Kelamin } \\
\hline Laki-laki & 47,45 \\
\hline Perempuan & 52,54 \\
\hline \multicolumn{2}{|l|}{ Umur } \\
\hline 0-4 tahun & 22,03 \\
\hline 5-9 tahun & 32,20 \\
\hline 10-15 tahun & 22,03 \\
\hline 16-21 tahun & 10,73 \\
\hline$>21$ tahun & 13,55 \\
\hline \multicolumn{2}{|l|}{ Tempat tinggal } \\
\hline Pedesaan & 90,96 \\
\hline Perkotaan & 9,04 \\
\hline \multicolumn{2}{|c|}{ Frekuensi ke Faskes } \\
\hline $1 \mathrm{kali}$ & 66,10 \\
\hline 2 kali & 23,16 \\
\hline$\geq 3$ kali & 2,82 \\
\hline \multicolumn{2}{|l|}{ Status Imunisasi } \\
\hline $\mathrm{Ya}$ & 59,32 \\
\hline Tidak & 28,24 \\
\hline Tidak Tahu & 12,42 \\
\hline \multicolumn{2}{|l|}{ Lama Sakit } \\
\hline$<10$ hari & 76,27 \\
\hline$\geq 10$ hari & 12,42 \\
\hline \multicolumn{2}{|l|}{ Pekerjaan } \\
\hline Bekerja & 9,60 \\
\hline Tidak bekerja & 90,39 \\
\hline \multicolumn{2}{|l|}{ Status Perawatan } \\
\hline Rawat Jalan & 82,48 \\
\hline Rawat Inap & 9,605 \\
\hline \multicolumn{2}{|c|}{ Kepemilikan Askes } \\
\hline $\mathrm{Ya}$ & 50,28 \\
\hline Tidak & 49,15 \\
\hline Tidak Tahu & 0,56 \\
\hline
\end{tabular}

Sebanyak 92\% orang mencari pengobatan dengan berkunjung ke fasilitas kesehatan. Sedangkan 14 orang (7,91\%) tidak berkunjung ke fasilitas kesehatan. Pemanfaatan jaminan kesehatan (Askes) hanya dilakukan 50,29\%. Tabel 2 menunjukkan karakteristik pasien KLB campak dalam mengunjungi fasilitas kesehatan.
Tabel 2. Distribusi frekuensi karakteristik pasien KLB campak dalam mengunjungi fasilitas kesehatan

\begin{tabular}{|c|c|c|}
\hline Variabel & Total $(n=177)$ & Persentase (\%) \\
\hline \multicolumn{3}{|l|}{ Mengunjungi faskes } \\
\hline $\mathrm{Ya}$ & 163 & 92,09 \\
\hline Tidak & 14 & 7,91 \\
\hline \multicolumn{3}{|l|}{ Menggunakan askes } \\
\hline $\mathrm{Ya}$ & 63 & 35,59 \\
\hline Tidak & 26 & 14,68 \\
\hline Tidak tahu & 88 & 49,71 \\
\hline \multicolumn{3}{|c|}{ Jenis faskes yang dikunjungi } \\
\hline Puskesmas & 82 & 50,30 \\
\hline Rumah sakit & 9 & 5,52 \\
\hline \multicolumn{3}{|l|}{ pemerintah } \\
\hline Rumah sakit swasta & 12 & 7,36 \\
\hline Klinik swasta & 60 & 36,81 \\
\hline \multicolumn{3}{|l|}{ Kelas Perawatan } \\
\hline Kelas satu & 5 & 29,41 \\
\hline Kelas dua & 4 & 23,52 \\
\hline Kelas tiga & 8 & 47,05 \\
\hline \multicolumn{3}{|c|}{ Jenis Transportasi ke faskes } \\
\hline Jalan kaki & 6 & 3,68 \\
\hline Transportasi umum & 1 & 0,6 \\
\hline Kendaraan pribadi & 146 & 89,57 \\
\hline Lainnya & 10 & 6,13 \\
\hline \multicolumn{3}{|c|}{ Total waktu untuk mencapai faskes } \\
\hline$<15$ menit & 60 & 37,42 \\
\hline 15-30 menit & 84 & 51,53 \\
\hline 30-60 menit & 18 & 11,04 \\
\hline$>60$ menit & 1 & 0,6 \\
\hline
\end{tabular}

Sebagian besar pasien KLB campak 146 orang $(89,57 \%)$ hanya menjalani rawat jalan saja, sementara 17 orang $(10,42 \%)$ menjalani rawat inap dan sebagian besar pasien yang menjalani rawat inap, yaitu 8 orang (47,05\%) menggunakan jenis perawatan kelas 3. Transportasi yang digunakan untuk menuju fasilitas kesehatan sebagian besar, yaitu sebanyak 146 orang $(89,7 \%)$ menggunakan kendaraan pribadi (sepeda motor, mobil pribadi) dan hanya 1 orang $(0,6 \%)$ yang menggunakan transportasi umum. Namun ada juga yang pergi ke fasilitas kesehatan dengan berjalan kaki, selain itu ada juga yang menggunakan ambulans milik rumah sakit atau klinik tempat mereka berobat. Total waktu tempuh yang dibutuhkan untuk mencapai fasilitas kesehatan cukup bervariasi, yang paling cepat adalah kurang dari 15 menit sebanyak 60 orang $(37,42 \%)$ kemudian 15-30 menit sebanyak 84 orang $(51,53 \%)$ dan yang paling lama adalah lebih dari 60 menit sebanyak 1 orang $(0,6 \%)$.

Tabel 3 menunjukkan total beban ekonomi akibat KLB campak di Provinsi DIY. Beban ekonomi mencapai Rp 37.506.900, rata-rata $\mathrm{Rp} 211.900$, median $\mathrm{Rp} 60.000$, IQR 172.000 (18.000, 190.000). Biaya tidak langsung meliputi produktivitas pasien yang hilang dan produktifitas keluarga yang hilang. 
Tabel 3. Total beban ekonomi akibat KLB campak di provinsi DIY tahun 2015

\begin{tabular}{|c|c|c|c|c|}
\hline Variabel & $\begin{array}{c}\text { Total } \\
(n=177)\end{array}$ & $\begin{array}{l}\text { Rata } \\
\text {-rata } \\
\text { (Rp) }\end{array}$ & $\begin{array}{l}\text { Median } \\
\text { (Rp) }\end{array}$ & $\begin{array}{l}\text { Interquartile } \\
\text { Range (IQR) }\end{array}$ \\
\hline \multicolumn{5}{|c|}{$\begin{array}{l}\text { Biaya langsung } \\
\text { Pasien Rawat } \\
\text { Jalan }(n=146)\end{array}$} \\
\hline Biaya Medis & 6.147 .000 & 42.400 & 10.000 & $\begin{array}{r}40.000 \\
(0,40.000)\end{array}$ \\
\hline $\begin{array}{l}\text { Biaya Non } \\
\text { Medis }\end{array}$ & 4.577 .900 & 31.300 & 10.000 & $\begin{array}{r}32.400 \\
(5.000,37400)\end{array}$ \\
\hline $\begin{array}{l}\text { Total Rawat } \\
\text { Jalan } \\
\text { Pasien Rawat } \\
\text { Inap }(n=17)\end{array}$ & 10.724 .900 & 73.450 & 33.500 & $\begin{array}{r}90.000 \\
(10.000,100.000)\end{array}$ \\
\hline Biaya Medis & 11.835 .000 & 699.200 & 450.000 & $\begin{array}{r}975.000 \\
(25000,1000.000)\end{array}$ \\
\hline $\begin{array}{l}\text { Biaya Non } \\
\text { Medis }\end{array}$ & 2.531 .000 & 148.900 & 110.000 & $\begin{array}{r}140.000 \\
(30.000,170.000)\end{array}$ \\
\hline $\begin{array}{l}\text { Total Rawat } \\
\text { Inap } \\
\text { Pasien Tidak } \\
\text { Berobat } \\
(n=14)\end{array}$ & 14.366 .000 & 845.050 & 560.000 & $\begin{array}{r}1.108 .000 \\
(142.000,1250.000)\end{array}$ \\
\hline $\begin{array}{l}\text { Biaya } \\
\text { Langsung }\end{array}$ & 696.000 & 49.700 & 40.000 & $\begin{array}{r}95.000 \\
(0,95.000)\end{array}$ \\
\hline $\begin{array}{l}\text { Total biaya } \\
\text { langsung }\end{array}$ & 25.786 .900 & 145.700 & 40.000 & $\begin{array}{r}100.000 \\
(10.000,110.000)\end{array}$ \\
\hline \multicolumn{5}{|c|}{ Biaya tak langsung } \\
\hline $\begin{array}{l}\text { Produktifitas } \\
\text { Pasien }(n=17)\end{array}$ & 3.998 .300 & 235.200 & 100.000 & $\begin{array}{r}300.000 \\
(50.000,350.000)\end{array}$ \\
\hline $\begin{array}{l}\text { Produktifitas } \\
\text { Keluarga } \\
(\mathrm{n}=58)\end{array}$ & 7.721 .700 & 133.100 & 333.000 & $\begin{array}{r}163.300 \\
(0,163.300)\end{array}$ \\
\hline $\begin{array}{l}\text { Total tak } \\
\text { langsung }\end{array}$ & 11.720 .000 & 156.300 & 166.700 & $\begin{array}{r}166.700 \\
(0,166.700)\end{array}$ \\
\hline $\begin{array}{l}\text { Beban } \\
\text { ekonomi }\end{array}$ & 37.506 .900 & 211.900 & 60.000 & $\begin{array}{r}172.000 \\
(18.000,190.000) \\
\end{array}$ \\
\hline
\end{tabular}

Tabel 4 menunjukkan beban ekonomi berdasarkan karakteristik rumah tangga.

Tabel 4. Beban ekonomi KLB campak berdasarkan karakteristik rumah tangga

\begin{tabular}{lcccr}
\hline \multicolumn{1}{c}{ Variabel } & $\begin{array}{c}\text { N=177 } \\
(\%)\end{array}$ & $\begin{array}{c}\text { Rata-rata } \\
\text { (Rp) }\end{array}$ & $\begin{array}{c}\text { Nilai } \\
\text { tengah } \\
\text { (Rp) }\end{array}$ & $\begin{array}{c}\text { Interquartile } \\
\text { Range (IQR) }\end{array}$ \\
\hline $\begin{array}{l}\text { Tempat } \\
\text { tinggal }\end{array}$ & & & & \\
Pedesaan & $161(90,96)$ & 226.900 & 80.000 & $(20.000,192.700)$ \\
Perkotaan & $16(9,04 \%)$ & 61.200 & 22.500 & $(11.000,92.000)$ \\
Pendidikan & & & & 1700 \\
KK & & & & 179000 \\
Tinggi & $116(65,53)$ & 261.300 & 100.000 & $(26.500,205.500)$ \\
Rendah & $61(34,46)$ & 118.050 & 39.300 & $(10.000,138.300)$ \\
Pendapatan & & & & 167.300 \\
RT & & & & 181.000 \\
Tinggi & $123(68,49)$ & 235.050 & 70.000 & $(20.000,187.300)$ \\
Rendah & $54(30,50)$ & 159.200 & 52.800 & $(17000,198000)$ \\
Jumlah ART & & & & 94.000 \\
$<4$ orang & $50(28,24)$ & 96.500 & 47.000 & $(16.000,110.000)$ \\
& & & & 192.000 \\
$\geq 4$ orang & $127(71,76)$ & 257.300100 .000 & $(18.000,210.000)$ \\
\hline
\end{tabular}

Beban ekonomi rumah tangga di pedesaan lebih tinggi jika dibandingkan dengan beban ekonomi rumah tangga yang tinggal di perkotaan. Berdasarkan pendidikan kepala keluarga, kepala keluarga dengan tingkat pendidikan tinggi, beban ekonomi juga lebih tinggi jika dibandingkan dengan kepala keluarga yang berpendidikan rendah. Rumah tangga berpendapatan tinggi memiliki beban ekonomi lebih tinggi jika dibandingkan dengan rumah tangga berpendapatan rendah. Berdasarkan jumlah anggota keluarga, rumah tangga dengan jumlah anggota $\geq 4$ orang (Tabel 4).

Beban ekonomi tertinggi pada pasien yang tidak diimunisasi. Pasien yang punya jaminan kesehatan mempunyai beban ekonomi lebih rendah jika dibandingkan pasien yang tidak mempunyai jaminan kesehatan (Tabel 5)

Tabel 5. Beban ekonomi KLB campak berdasarkan karakteristik pasien

\begin{tabular}{|c|c|c|c|c|}
\hline Variabel & $\begin{array}{c}\mathrm{N}=177 \\
(\%)\end{array}$ & $\begin{array}{c}\text { Rata-rata } \\
\text { (Rp) }\end{array}$ & $\begin{array}{c}\text { Nilai } \\
\text { tengah } \\
\text { (Rp) }\end{array}$ & $\begin{array}{c}\text { Interquartile } \\
\text { Range (IQR) }\end{array}$ \\
\hline \multicolumn{5}{|l|}{$\begin{array}{l}\text { Jenis } \\
\text { kelamin }\end{array}$} \\
\hline Laki-laki & $84(47,45)$ & 211.250 & 80.000 & $\begin{array}{r}160.500 \\
(19.700,180.200)\end{array}$ \\
\hline Perempuan & $93(52,54)$ & 212.500 & 58.000 & $\begin{array}{r}176.600 \\
(17.400,194.000)\end{array}$ \\
\hline \multicolumn{5}{|l|}{ Usia } \\
\hline 0-4 tahun & $39(22,03)$ & 383.800 & 100.000 & $\begin{array}{r}320.000 \\
(25.000,345.000)\end{array}$ \\
\hline 5-9 tahun & $57(32,20)$ & 184.650 & 58.000 & $\begin{array}{r}170.000 \\
(20.000,190.000)\end{array}$ \\
\hline 10-15 tahun & $39(22,03)$ & 202.300 & 80.000 & $\begin{array}{r}126.000 \\
(24.000,150.000)\end{array}$ \\
\hline 16-21 tahun & $19(10,73)$ & 116.500 & 110.000 & $\begin{array}{r}136.700 \\
(13.300,150.000) \\
445.000\end{array}$ \\
\hline$>21$ tahun & $23(12,99)$ & 82.400 & 20.000 & $(105.000,550.000)$ \\
\hline \multicolumn{5}{|l|}{$\begin{array}{l}\text { Status } \\
\text { Imunisasi }\end{array}$} \\
\hline Ya & $105(59,32)$ & 143.550 & 80.000 & $\begin{array}{r}133.300 \\
(20.000,153.300)\end{array}$ \\
\hline Tidak & $50(28,24)$ & 338.900 & 64.000 & $\begin{array}{r}497.300 \\
(16.000,513.300)\end{array}$ \\
\hline Tidak Tahu & $22(12,42)$ & 249.200 & 55.000 & $\begin{array}{r}99.000 \\
(11.000,110.000)\end{array}$ \\
\hline \multicolumn{5}{|l|}{ Lama Sakit } \\
\hline$<10$ hari & $135(76,27)$ & 145.050 & 50.000 & $\begin{array}{r}130.000 \\
(16.000,146.000)\end{array}$ \\
\hline$\geq 10$ hari & $42(26,55)$ & 426.700 & 191.350 & $\begin{array}{r}594.500 \\
(29.000,623.500)\end{array}$ \\
\hline \multicolumn{5}{|l|}{$\begin{array}{l}\text { Status } \\
\text { rawat }\end{array}$} \\
\hline Inap & $17(9,60)$ & 971.900 & 62.500 & $\begin{array}{r}1.351 .300 \\
(232.000,1.583 .3 \\
00\end{array}$ \\
\hline \multicolumn{5}{|l|}{$\begin{array}{l}\text { Jaminan } \\
\text { kesehatan }\end{array}$} \\
\hline Ya & $89(50,28)$ & 147.500 & 50.000 & $\begin{array}{r}140.000 \\
(10.000,150.000)\end{array}$ \\
\hline Tidak & $87(49,15)$ & 279.740 & 100.000 & $\begin{array}{r}241.000(35.000,2 \\
76.000)\end{array}$ \\
\hline Tidak tahu & $1(0,56)$ & 33.000 & 33.000 & $0(33.000,33000)$ \\
\hline
\end{tabular}


Berdasarkan Kabupaten, dapat diketahui bahwa biaya langsung yang tertinggi adalah di wilayah Kabupaten Sleman, kemudian tertinggi kedua ada di wilayah Kabupaten Bantul. Biaya langsung yang paling rendah ada di wilayah Kota Yogyakarta, sedangkan untuk biaya tidak langsung tertinggi ada di wilayah Kabupaten Kulon Progo dan yang paling rendah ada di
Kota Yogyakarta. Beban ekonomi akibat KLB Campak yang paling tinggi adalah di Kabupaten Sleman. Jumlah ini setara dengan 35,60\% dari total beban ekonomi akibat KLB Campak di Provinsi DIY. Beban ekonomi paling rendah adalah di wilayah Kota Yogyakarta yaitu Rp 1.661 .800 (rata-rata $\mathrm{Rp} 79.100$ ) hanya 12,30\% dari total beban ekonmi akibat KLB Campak di Provinsi DIY (Tabel 6).

Tabel 6. Beban ekonomi KLB campak berdasarkan Kabupaten/Kota di Provinsi DIY Tahun 2015

\begin{tabular}{lcccccrc}
\hline \multirow{2}{*}{ Kab/kota } & Jml & \multicolumn{9}{c}{ Variabel } \\
\cline { 3 - 8 } & $\mathbf{n}(\%)$ & Biaya langsung & Mean & $\begin{array}{c}\text { Biaya tak } \\
\text { langsung }\end{array}$ & Mean & $\begin{array}{c}\text { Beban } \\
\text { Ekonomi }\end{array}$ & Mean \\
\hline Bantul & $33(18,64)$ & 4.804 .500 & 145.600 & 1.550 .000 & 46.970 & 6.354 .500 & 192.550 \\
Kulon Progo & $66(37,28)$ & 3.361 .900 & 50.900 & 6.473 .300 & 98.100 & 9.835 .200 & 149.000 \\
Sleman & $27(15,24)$ & 11.512 .000 & 426.400 & 1.843 .300 & 68.272 & 13.355 .300 & 494.600 \\
Gunung Kidul & $30(1,69)$ & 4.680 .000 & 156.000 & 1.620 .000 & 54.000 & 6.300 .000 & 210.000 \\
Yogyakarta & $21(11.86)$ & 1.428 .500 & 68.000 & 233.300 & 11.100 & 1.661 .800 & 79.100 \\
\hline Provinsi DIY & 177 & 25.786 .900 & 145.700 & 11.720 .000 & 66.215 & 37.506 .900 & 211.903 \\
\hline
\end{tabular}

\section{Hubungan karakteristik rumah tangga dengan beban ekonomi KLB campak}

Berdasarkan analisis multivariat, variabel yang diduga paling berhubungan dengan beban ekonomi KLB campak adalah status perawatan pasien $(\mathrm{p}=0.00)$ dan variabel lama sakit $(p=0.02)$ yaitu bahwa pasien rawat inap dan lama perawatan lebih dari 10 hari akan menanggung beban ekonomi lebih tinggi.

\section{BAHASAN}

Penelitian menunjukkan bahwa beban ekonomi akibat KLB campak di provinsi DIY mencapai $\mathrm{Rp}$ 37.506.900, yang merupakan beban ekonomi dari pasien rawat jalan maupun rawat inap. Komponen biaya yang dominan dalam beban ekonomi akibat KLB campak di Provinsi DIY adalah biaya langsung jika dibandingkan dengan biaya tidak langsung. Biaya langsung pada pasien rawat jalan dan rawat inap mencapai Rp 25.786.900 dan komponen yang tertinggi pada biaya langsung baik pada pasien rawat jalan maupun rawat inap adalah biaya medis (biaya langsung medis rawat jalan $\mathrm{Rp}$ 6.147.000, Biaya langsung medis rawat inap $\mathrm{Rp}$ 11.835.00) sedangkan biaya tidak langsung hanya $\mathrm{Rp} 11.720 .000$ yang meliputi hilangnya produktifitas pasien akibat tidak bisa masuk kerja karena terkena campak sebesar $\mathrm{Rp}$ 3.998.300 dan hilangnya produktifitas anggota rumah tangga akibat menunggui, mengantar atau menjaga pasien campak yaitu sebesar Rp 7.721.700.

Berdasarkan hasil penelitian total biaya langsung medis Rp 17.982.000, sedangkan biaya langsung non medis $\mathrm{Rp} 7.804 .900$, sehingga total biaya langsung $\mathrm{Rp}$
25.786.900, atau rata-rata $\mathrm{Rp} 145.700$ per kasus. Jumlah ini setara dengan $6,33 \%$ dari rata-rata pendapatan rumah tangga pasien KLB campak di Provinsi DIY. Hasil penelitian ini sesuai dengan penelitian yang dilakukan oleh Wallace et al. yang melakukan penelitian terkait beban ekonomi KLB campak dari perspektif rumah tangga maupun sektor kesehatan yang di lakukan di Keffa Ethiopia dengan hasil bahwa biaya yang dikeluarkan sektor rumah tangga untuk pengobatan campak sekitar $6 \%$ dari pendapatan rumah tangga di Ethiopia (6).

Komponen biaya langsung tertinggi adalah pada biaya langsung medis. Besarnya biaya langsung medis terutama terjadi pada pasien yang menjalani rawat inap yaitu sebanyak 17 pasien (10,42\%) dengan biaya langsung medis sebesar Rp11.835.000, dengan lama perawatan rata-rata 4 hari. Hal ini terjadi karena pasien rawat inap harus membayar biaya kamar, biaya perawatan, dan biaya obat yang jumlah dan variasinya lebih banyak jika dibandingkan pasien rawat jalan. Pasien rawat inap merupakan pasien KLB campak yang biasanya disertai dengan tingkat keparahan penyakit yang tinggi, sehingga mereka memerlukan obat dengan jenis yang lebih banyak dan perawatan ekstra. Sehingga biaya rawat inap merupakan komponen yang paling tinggi yaitu mencapai $\mathrm{Rp}$ 14.366.000. Hasil ini sesuai dengan penelitian yang dilakukan oleh Filia et.al yang melakukan penelitian terkait beban ekonomi KLB campak di Italia pada 2002-2003 yang menunjukan bahwa biaya untuk rawat inap akibat KLB campak pada tahun 2002-2003 di Italia sangat tinggi, dengan asumsi bahwa biaya rawat inap berkisar antara 40-50\% dari total biaya langsung (€17.6 
juta). Sedangkan penelitian di DIY menunjukan bahwa biaya rawat inap mencapai $55,71 \%$ dari total biaya langsung (4).

Biaya tidak langsung adalah hilang produktifitas karena tidak bisa bekerja akibat sakit. Total produktifitas yang hilang dari 15 pasien (8.47\%) adalah $\mathrm{Rp}$ 3.998.300. Sedangkan total produktifitas yang hilang dari anggota rumah tangga yang berjumlah $58(32,76 \%)$ adalah Rp 7.721.700. Produktifitas yang hilang dari anggota keluarga jauh lebih tinggi daripada produktifitas yang hilang dari pasien. Hasil ini sesuai dengan penelitian Wallace et al (2014) yang menyatakan bahwa produktifitas yang hilang dari anggota keluarga cukup tinggi akibat mengantar, menunggui dalam masa pemulihan penyakit campak (6).

\section{Beban ekonomi berdasarkan karakteristik rumah tangga}

Rumah tangga yang berdomisili di pedesaan menanggung beban ekonomi lebih tinggi daripada rumah tangga yang berdomisili di perkotaan. Hal ini berhubungan dengan akses pelayanan kesehatan yang yang cukup sulit dan waktu tempuh lama, diduga rumah tangga di pedesaan belum mengunjungi fasilitas kesehatan ketika sakit belum parah. Ketika sakit sudah parah, pasien baru dibawa ke fasilitas kesehatan. Hal ini menyebabkan rumah tangga akan menanggung beban ekonomi lebih besar. Faktor-faktor yang memengaruhi layanan kesehatan adalah jarak tempuh layanan kesehatan, jarak pelayanan kesehatan yang jauh akan mengurangi motivasi untuk berkunjung ke layanan kesehtan.

Kepala keluarga yang berpendidikan tinggi mempunyai beban ekonomi yang lebih tinggi daripada rumah tangga dengan pendidikan rendah. Hal ini dimungkinkan karena seseorang yang berpendidikan tinggi akan lebih termotivasi untuk segera pergi ke fasilitas kesehatan jika ada anggota rumah tangga yang sakit. Dalam hal memilih fasilitas kesehatan sesorang dengan pendidikan tinggi akan memperhatikan kualitas dan mutu pelayanan kesehatan yang dikunjungi, sehingga hal ini akan menyebabkan biaya meningkat.

Peningkatan permintaan akan layanan kesehatan di masyarakat dipengaruhi oleh dua hal, yaitu pertama peningkatan jumlah penduduk, menyebabkan kebutuhan akan layanan kesehatan meningkat; kedua peningkatan kualitas dari penduduk tersebut, dimana dengan pendidikan yang tinggi, maka akan membutuhkan layanan kesehatan yang lebih baik pula (7). Tingkat pendidikan tinggi menyebabkan seseorang lebih mengetahui rIsiko penyakit yang bisa muncul, sehingga hal ini memengaruhi permintaan layanan kesehatan yang lebih baik dan berdampak pada peningkatan biaya kesehatan.

Rumah tangga dengan pendapatan tinggi mempunyai beban ekonomi lebih tinggi jika dibandingkan pada rumah tangga dengan pendapatan rendah. Hal ini terkait dengan perilaku. Seseorang dengan tingkat ekonomi tinggi cenderung lebih memperhatikan faktor kesehatan sehingga mereka rela mengeluarkan biaya kesehatan lebih besar. Sedangkan pada seseorang dengan tingkat ekonomi rendah cenderung kurang perhatian dengan masalah kesehatan. Orang miskin sangat kecil kemungkinan mencari perawatan medis, bahkan ketika sangat dibutuhkan karena jarak yang jauh dengan fasilitas kesehatan dan terbatas uang untuk pembiayaan kesehatan dan pengetahuan yang rendah tentang penanganan penyakit (8).

Jumlah anggota lebih dari 4 orang akan menanggung beban ekonomi lebih tinggi jika dibandingkan dengan beban ekonomi pada rumah tangga dengan jumlah anggota kurang dari 4 orang. Jumlah anggota rumah tangga berkaitan dengan beban tanggungan. Semakin banyak anggota rumah tangga, beban tanggungan akan semakin tinggi. Pada kondisi seperti ini biasanya rumah tangga kurang memperhatikan masalah kesehatan terutama masalah konsumsi makanan, sehingga berpotensi menimbulkan masalah kekurangan gizi pada keluarga dan ketika seseorang dengan defisiensi gizi terkena penyakit maka penyakitnya cenderung lebih berat, sehingga sakitnya cenderung lebih lama dan akan meningkatkan biaya sakit. Campak pada penderita defisiensi gizi akan lebih berat jika dibandingkan dengan campak pada seseorang dengan gizi yang baik. Sehingga dimungkinkan penderita campak pada rumah tangga dengan jumlah lebih dari 4 adalah penderita campak yang berat sehingga perlu waktu pemulihan yang lama dan memerlukan biaya perawatan yang lebih tinggi.

\section{Beban ekonomi berdasarkan karakteristik pasien}

Beban ekonomi pada pasien perempuan lebih tinggi dibandingkan dengan beban ekonomi pada laki-laki, walaupun selisihnya tidak terlalu jauh. Hal ini bisa dimungkinkan karena jumlah kasus campak di provinsi DIY lebih tinggi pada perempuan dan frekuensi ke fasilitas kesehatan juga lebih tinggi pada perempuan yaitu 25 orang (17,12\%) pasien campak perempuan mengunjungi fasilitas kesehatan lebih dari 2 kali, sedangkan pasien laki-laki yang mengunjungi fasilitas kesehatan lebih dari 2 kali hanya 16 orang (10,95\%) sehingga beban ekonomi pada pasien perem- 
puan lebih tinggi. Jenis kelamin akan memengaruhi kebutuhan layanan kesehatan, dimana perempuan akan lebih sering mengunjungi pelayanan kesehatan terutama saat mengandung dan melahirkan.

Usia 0-4 tahun mempunyai beban ekonomi paling tinggi daripada kelompok umur lain. Hal ini dimungkinkan pada penderita campak usia 0-4 tahun lebih rentan mengalami komplikasi dibandingkan usia dewasa, sehingga pada usia 0-4 tahun akan lebih sering mengakses pelayanan kesehatan. Usia bayi dan anakanak kebutuhan akan layanan kesehatan cenderung naik dan akan menurun saat usia remaja dan dewasa. Menurut Kementerian Kesehatan, sebagian besar penderita campak akan sembuh. Komplikasi sering terjadi pada anak usia $<5$ tahun dan penderita dewasa usia $>20$ tahun, penderita malnutrisi dan defisiensi vitamin A.

Pasien yang tidak diimunisasi mempunyai beban ekonomi yang lebih tinggi daripada pasien yang diimunisasi. Hal ini dimungkinkan karena pasien yang tidak diimunisasi cenderung mengalami sakit campak yang lebih berat daripada pasien yang diimunisasi. Pada dasarnya tujuan imunisasi adalah untuk meningkatkan kekebalan seseorang secara aktif terhadap suatu penyakit, sehingga apabila kelak seseorang tersebut terkena penyakit, tidak akan sakit/ sakit ringan (2).

Berdasarkan lama sakit, pasien dengan lama sakit lebih dari 10 hari mempunyai beban ekonomi yang lebih tinggi jika dibandingkan dengan pasien yang lama sakitnya kurang dari 10 hari. Hal ini dimungkinkan karena pasien dengan lama sakit lebih dari10 hari merupakan pasien campak yang disertai dengan komplikasi sehingga memerlukan perawatan kesehatan yang lebih intensif dan akan lebih sering berkunjung ke fasilitas kesehatan. Lama sakit campak akan mengelurakan biaya ekonomi rumah tangga yang lebih besar (6).

Berdasarkan kepemilikan jaminan kesehatan, pasien yang tidak mempunyai jaminan kesehatan mempunyai beban ekonomi lebih tinggi daripada pasien yang mempunyai jaminan kesehatan. Tujuan dari asuransi kesehatan adalah untuk mengendalikan biaya kesehtan, sehingga kemungkinan bagi yang tidak mempunyai jaminan kesehatan akan lebih besar menanggung beban ekonomi jika terkena penyakit. Berdasarkan Undang-undang Nomor 24 Tahun 2011, tentang BPJS (Badan Penyelenggara Jaminan Sosial) bahwa tujuan dari BPJS adalah untuk mewujudkan terselenggaranya pemberian jaminan, terpenuhinya kebutuhan dasar hidup yang layak bagi setiap peserta dan atau anggota keluarganya, sehingga bagi peserta
BPJS jika terkena penyakit beban ekonomi yang ditanggung akan lebih ringan.

Berdasarkan analisis regresi linier, dapat diketahui bahwa variabel yang paling berhubungan dengan beban ekonomi KLB campak adalah status keperawatan pasien dan variabel lama sakit yang berarti bahwa pasien rawat inap dan lama perawatan lebih dari 10 hari akan menanggung beban ekonomi lebih tinggi. Hal ini dimungkinkan karena pada pasien rawat inap biasanya merupakan pasien KLB campak dengan tingkat keparahan yang cukup tinggi atau komplikasi, sehingga perlu perawatan ekstra dan memerlukan biaya lebih tinggi. Penelitian senada juga pernah dilakukan oleh Suijkerbuijk et al di Belanda yang menyatakan bahwa komplikasi penyakit campak akan membutuhkan biaya finansial yang cukup tinggi (5).

Lama sakit menjadi faktor penting dalam estimasi beban ekonomi akibat KLB campak, durasi sakit yang lebih dari 10 hari akan meningkatkan beban ekonomi akibat KLB campak. Berdasarkan hasil penelitian menunjukan bahwa 42 orang (23\%) mengalami sakit campak lebih dari 10 hari, yang tentunya akan meningkatkan beban ekonomi. Penelitian serupa pernah dilakukan oleh Wallace et al yang menyatakan bahwa durasi sakit campak yang lama akan meningkatkan biaya ekonomi rumah tangga (6).

Keterbatasan penelitian berkaitan dengan definisi kasus campak yang meliputi klinis, epidemiologis dan konfirmasi laboratorium. Kasus klinis dan epidemiologis mungkin tidak selalu menjadi campak setelah dikonfirmasi laboratorium. Beberapa penyakit lain termasuk rubella dapat menunjukkan gejala klinis yang sama seperti campak (bias seleksi). Biaya rumah tangga yang dikeluarkan untuk biaya penyakit campak bisa menjadi bias terutama pada kasus dan biaya yang dikeluarkan selama periode Mei 2014-2015/ \pm satu tahun sebelum hari wawancara (recall bias).

\section{SIMPULAN}

Biaya langsung yang harus ditanggung pasien KLB Campak di Provinsi DIY adalah sebesar Rp. 25.786.900 rata-rata Rp 145.700 per kasus. Komponen biaya langsung yang dominan adalah biaya rawat inap (setara dengan 55\% dari total biaya langsung). Biaya tidak langsung yang harus ditanggung pasien KLB campak di Provinsi DIY sebesar Rp 11.720.000 sehingga beban ekonomi yang harus ditanggung pasien KLB campak di Provinsi DIY sebesar Rp 37.506.900, rata-rata $\mathrm{Rp} 211.900$ perkasus. Beban ekonomi ini setara dengan 9,20\% dari total pendapatan rumah tangga pasien KLB. 
Faktor yang berhubungan dengan tingginya beban ekonomi adalah variabel rawat inap dan lama sakit lebih dari 10 hari. Perlu advokasi masyarakat terkait pencegahan campak dengan imunisasi campak serta komunikasi, informasi dan edukasi supaya masyarakat memanfaatkan jaminan kesehatan yang telah dimiliki. Perlu kajian yang mendalam terkait budaya penolakan imunisasi di Provinsi DIY.

\begin{abstract}
Abstrak
Tujuan: Penelitian ini bertujuan untuk menganalisis beban ekonomi akibat wabah campak di sektor rumah tangga di Yogyakarta. Metode: This research was a descriptive study with survey design, with data collected of direct and indirect costs for patients exposed to measles, by conducting interviews of 177 respondents using a questionnaire. Secondary data was compared in the form of outbreaks of measles in 2014 and 2015, to research in February-March, 2016.

Hasil: Jumlah pasien KLB campak yang mengunjungi fasilitas kesehatan mencapai 163 pasien (92,09\%). Total biaya medis adalah $\mathrm{Rp}$ 17.982.000, biaya non-medis IDR 7.804.900, sehingga total biaya langsung $\quad \mathrm{Rp}$ adalah $25.786 .900 \quad$ (rata-rata Rp.145.700). Total biaya tidak langsung adalah $\mathrm{Rp}$ 11.720.000 (rata-rata Rp 156.300). Beban ekonomi wabah campak adalah Rp 37.506.900 (rata-rata Rp 211. 900). Umumnya, biaya yang dibayarkan sebesar 6,32\% dari pendapatan rumah tangga, belum dianggap bencana. Analisis regresi menunjukkan durasi penyakit rata-rata lebih dari 10 hari $(p=0,002)$ dengan beberapa status rawat inap $(p=0,000)$. Simpulan: Beban ekonomi wabah campak di provinsi pada tahun 2015 adalah Rp 37.506.900, termasuk biaya langsung dan tidak langsung. Biaya medis adalah komponen biaya langsung yang dominan. Faktor- faktor yang terkait dengan beban ekonomi adalah durasi penyakit lebih dari 10 hari dan status rawat inap. Perlu ada advokasi kepada masyarakat tentang penggunaan perawatan kesehatan dan pencegahan campak melalui imunisasi campak.
\end{abstract}

Kata Kunci: biaya; beban ekonomi; KLB campak

\section{PUSTAKA}

1. WHO. Chapter 7: Measles. VPD Surveillance Manual 6th Edition 2013, 1-21. 2013.

2. Kemenkes, P. D. dan I. Infodatin-imunisasi.pdf (April 2014., pp. 1-8). Jakarta: Kemenkes RI. 2013.

3. Takahashi K, Ohkusa Y, Kim JY. The economic disease burden of measles in Japan and a benefit cost analysis of vaccination, a retrospective study. BMC health services research. 2011 Oct 7;11(1):254.

4. Filia A, Brenna A, Panà A, Cavallaro GM, Massari M, degli Atti ML. Health burden and economic impact of measles-related hospitalizations in Italy in 2002-2003. BMC Public Health. 2007 Jul 24;7(1):169.

5. Suijkerbuijk AW, Woudenberg T, Hahné SJ, Lochlainn LN, de Melker HE, Ruijs WL, Lugnér AK. Economic costs of measles outbreak in the Netherlands, 2013-2014. Emerging infectious diseases. 2015 Nov;21(11):2067.

6. Wallace AS, Masresha BG, Grant G, Goodson JL, Birhane H, Abraham M, Endailalu TB, Letamo Y, Petu A, Vijayaraghavan M. Evaluation of economic costs of a measles outbreak and outbreak response activities in Keffa Zone, Ethiopia. Vaccine. $2014 \mathrm{Jul}$ 31;32(35):4505-14.

7. Notokususmo, A. Analisis Faktor-faktor yang mempengaruhi Biaya Pelayanan Kesehatan Rawat Jalan di Sarana Pelayanan Kesehtan yang dilanggan PT Perusahaan Listrik Nasional Batam Tahun 2009. Tesis FKM UI, 2009,1-106. 2009.

8. Wulan, S. Beban Ekonomi Yang Ditanggung Pasien dan Anggota Rumah Tangga Akibat Penyakit Tuberculosis di Kota Bengkulu, Tesis, Susilo Wulan, FKM UI, 2014, 1-152. 2014. 